\title{
Sustainability of water resources management in the Indus Basin under changing climatic and socio economic conditions
}

\author{
D. R. Archer ${ }^{1,2}$, N. Forsythe ${ }^{1}$, H. J. Fowler ${ }^{1}$, and S. M. Shah ${ }^{3}$ \\ ${ }^{1}$ Water Resource Systems Research Laboratory, School of Civil Engineering and Geosciences, Newcastle University, UK \\ ${ }^{2}$ JBA Consulting Engineers and Scientists, South Barn, Broughton Hall, Skipton, North Yorks., BD23 3AE, UK \\ ${ }^{3}$ Centre of Excellence in Water Resources Engineering, University of Engineering and Technology, G. T. Road, 54890, \\ Lahore, Pakistan
}

Received: 25 February 2010 - Published in Hydrol. Earth Syst. Sci. Discuss.: 15 March 2010

Revised: 15 July 2010 - Accepted: 25 July 2010 - Published: 27 August 2010

\begin{abstract}
Pakistan is highly dependent on water resources originating in the mountain sources of the upper Indus for irrigated agriculture which is the mainstay of its economy. Hence any change in available resources through climate change or socio-economic factors could have a serious impact on food security and the environment. In terms of both ratio of withdrawals to runoff and per-capita water availability, Pakistan's water resources are already highly stressed and will become increasingly so with projected population changes. Potential changes to supply through declining reservoir storage, the impact of waterlogging and salinity or over-abstraction of groundwater, or reallocations for environmental remediation of the Indus Delta or to meet domestic demands, will reduce water availability for irrigation.

The impact of climate change on resources in the Upper Indus is considered in terms of three hydrological regimes - a nival regime dependent on melting of winter snow, a glacial regime, and a rainfall regime dependent on concurrent rainfall. On the basis of historic trends in climate, most notably the decline in summer temperatures, there is no strong evidence in favour of marked reductions in water resources from any of the three regimes. Evidence for changes in transHimalayan glacier mass balance is mixed. Sustainability of water resources appears more threatened by socio-economic changes than by climatic trends. Nevertheless, analysis and the understanding of the linkage of climate, glaciology and runoff is still far from complete; recent past climate experience may not provide a reliable guide to the future.
\end{abstract}

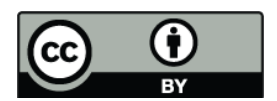

Correspondence to: D. R. Archer (david.archer@jbaconsulting.co.uk)

\section{Introduction}

The Greek historian Herodotus (5th century BC) described Egypt as "the gift of the Nile" and "as a land won by the Egyptians and given them by the Nile". These remarks could equally be applied to the relationship between Pakistan and the River Indus and its major tributaries, the Jhelum, Chenab, Ravi, Beas and Sutlej. The fertility of the alluvial plains of Pakistan derives from sediments deposited over geological time by the Indus from the high mountain ranges of the Himalaya-Karakoram-Hindu Kush (HKH). The continuing flow of water across the plains is largely derived from the same source and provides the basis for irrigated agriculture which is the mainstay of Pakistan's economy. Mountain sources of flow in the Indus are vulnerable both to changes in temperature and precipitation as most of the runoff is derived from the melting of seasonally accumulated snow and ice from glaciers. Hence changes in climate or the resulting accumulation of snow and ablation of glaciers in the upper reaches of the river could have serious consequences for the livelihoods not only of those engaged in the agricultural sector but for the economy as a whole.

Concerns about the impact of climate change on the Indus, based on an assessment of what might happen, given temperature changes in line with global climate change projections (Rees and Collins, 2005; Akhtar et al., 2008), have given rise to expectations of dramatic decreases in river flow (Briscoe and Qamar, 2007). Such concerns have been supported by reports of significant retreat and depletion of glacier volume across the HKH (Himalaya-Karakoram-Hindukush), (Eriksson, 2009; Berthier, 2007; Shrestha et al., 2004).

Published by Copernicus Publications on behalf of the European Geosciences Union. 
However, the effects of climate change on glaciers and on river flow in the western HKH are not yet clear. Fowler and Archer (2006) have shown that although mean annual temperatures are generally rising in line with the global average, summer temperatures (July to September), the key for glacial melt, have been falling at many valley stations in the Karakoram in the period 1961 to 2000. Hussain et al. (2005) showed similar temperature falls in both the monsoon and pre-monsoon (April-May) period for the "high mountain region". In addition, Archer and Fowler (2004) indicated that there have been significant increases in precipitation in the Upper Indus in both winter and summer in the period 1961 to 1999. Reports on glacial mass balance by Hewitt (1998, 2005) on the basis of extensive field experience over several decades also contrast with reports elsewhere of shrinking glaciers. Hewitt (2005) notes that in the late 1990s there was widespread evidence of glacier expansion mainly in high level glaciers in the central Karakoram.

Such conflicting views on what changes have occurred in the climate and glaciers of the Upper Indus Basin have serious implications for future water management in Pakistan and for the sustainability of water resources, through the resulting impact on downstream flows reaching the irrigated plains of the Punjab and Sindh. Climate change impacts are considered in more detail later in this paper.

The relationship between climate change and water resources is of primary concern to human society. However, the relationship does not exist in isolation and is affected by socio-economic and environmental conditions which influence the balance between supply and demand. It is necessary to consider also how freshwater resources have been, and will be, affected by changes in these non-climatic drivers (Bates et al., 2008).

\section{Geographical and hydrological background}

The River Indus rises on the Tibetan Plateau and in its passage through India and Pakistan it drains the highest mountain ranges of the world (Fig. 1). The basin is sometimes referred to as the "Third Pole" and contains the greatest area of perennial ice outside the Polar Regions $\left(>20000 \mathrm{~km}^{2}\right)$; the area of winter snow cover is an order of magnitude greater.

The climate of the Upper Indus is influenced by the disposition and height of mountain ranges; the monsoon, which brings significant rainfall on the southern margin, penetrates infrequently across the Himalayan mountain divide. Precipitation in the trans-Himalayan Karakoram and Hindu Kush ranges primarily occurs as snow in winter and spring as the result of westerly disturbances. Even so, valley climate stations at elevations below $2500 \mathrm{~m}$ a.s.l. record annual rainfalls of generally less than $200 \mathrm{~mm}$, and the maximum annual precipitation of over $1500 \mathrm{~mm}$ occurs at elevations above $5000 \mathrm{~m}$ (Wake, 1989). Given the limited precipitation at low levels, the main hydrological activities of melt of seasonal

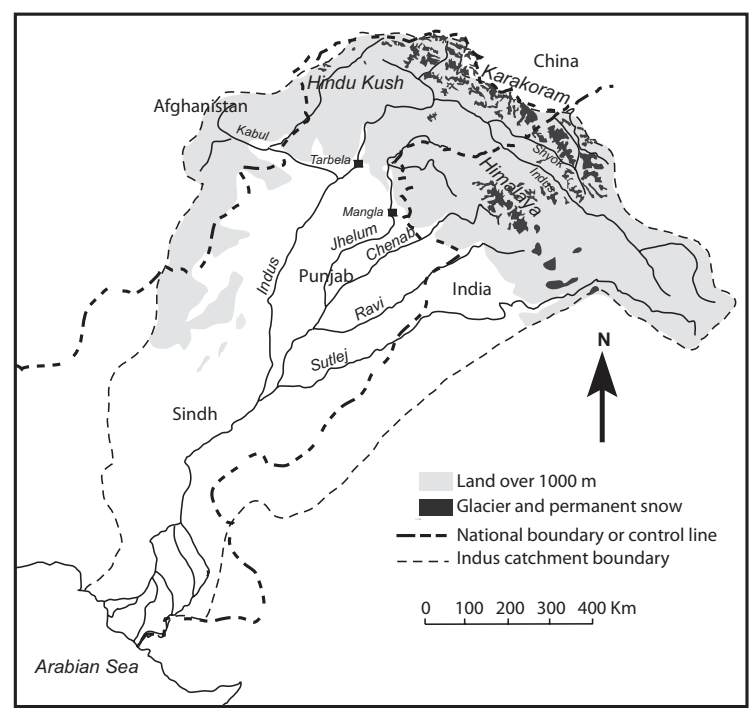

Fig. 1. The Indus Basin.

snow and glaciers occur at elevations above $4000 \mathrm{~m}$ and contribute towards river runoff from March to September. A combined annual average volume of about $175 \times 10^{9} \mathrm{~m}^{3}$ (billion cubic metres $-\mathrm{bcm}$ ) (equivalent to an average discharge of $5550 \mathrm{~m}^{3} \mathrm{~s}^{-1}$ ) for all major rivers is discharged into the Indus plains.

A summer monsoon maximum occurs on the southern slopes of the Himalaya although winter totals are also enhanced with annual rainfall up to $1800 \mathrm{~mm}$ (Archer and Fowler, 2004). Southward from the foothills rainfall totals decline rapidly and much of the lower Indus receives an annual average total of less than $200 \mathrm{~mm}$.

The arid and semi-arid environment of the plains does not provide a reliable basis for rain-fed agriculture and, until the development of irrigation systems in the British colonial era, the land, except in the immediate vicinity of river channels, was largely used for pastoralism. The Indus Basin Irrigation System (IBIS), comprising the major storage reservoirs of Tarbela on the Indus and Mangla on the Jhelum and a network of barrages and canals, has now grown to be the largest integrated irrigation system in the world. The irrigation command area of approximately 18 million hectares is $78 \%$ of Pakistan's total cultivated area of $23 \mathrm{M}$ hectares (Habib, 2004). The Indus River and its tributaries provide nearly $60 \%$ of the water utilized for irrigation. Much of the remainder is groundwater which is recharged by the rivers and by the leaking canal network. Irrigated land accounts for $85 \%$ of all cereal grain production (mainly rice and wheat), all sugar production and most of the cotton production. Most people in rural and urban Pakistan depend on groundwater for their drinking water. Of the major cities, only Karachi and Islamabad rely primarily on surface water sources.

Pakistan's agricultural sector is dominant in the economy of Pakistan. The sector not only meets the food demand of 
the growing population but also provides the raw materials for the industrial sector, notably cotton for the textile industry. The sector employs around $45 \%$ of the total labour force of the country whilst the $67 \%$ of the population living in rural areas is linked directly or indirectly to agriculture for their livelihoods. Textiles comprise $64 \%$ and food products $11 \%$ of total Pakistani exports; both are wholly dependent on agriculture. The linkage between water resources, through irrigation demand, to the economic wellbeing of the country is thus established.

The geopolitical situation of Pakistan has also had a profound effect on water resources development. Partition in 1947 divided the source rivers of the Indus Basin in India from irrigated land in Pakistan. The Indus Waters Treaty, eventually agreed in 1960, gave Pakistan the exclusive use of waters of the three western tributaries, the Indus, Jhelum and Chenab, and India the eastern rivers, Sutlej, Beas and Ravi to their entry point to Pakistan. An important element of the Treaty was the construction of infrastructure which would enable Pakistan to continue supply to irrigated areas on the eastern rivers. This included the two main storage dams, Mangla on the Jhelum, completed in 1967, and Tarbela on the Indus, commissioned in 1978, and the building of link canals from the western rivers to the east.

The developments enabled an increase in the area under irrigation by 15 to $20 \%$ and a significant increase in cropping intensities. In particular, it allowed the transfer of surplus water from storage in the summer period to the spring. The spring (rabi) crop is mainly of wheat which is by far the most important crop in Pakistan with a planted area of over 8 million hectares and is the staple food for the majority of the population. Nevertheless, in many years home production is insufficient to meet demand and annual imports of more than 2 million tons of wheat have had to be made. Food security is an important element in sustainability of water resources management.

\section{Water stress - the supply demand balance}

Water stress has typically been defined in two ways:

1. as a ratio of withdrawals to long-term average annual runoff (Alcamo et al., 2003), or

2. in terms of per capita water availability (UNDP; UNEP; World Bank; and WRI, 2000).

\subsection{Ratio of withdrawals to runoff}

In terms of ratio of withdrawals to runoff, water stress is defined to occur when the ratio rises above 0.4. This threshold was used by a consortium of United Nations organizations (Raskin et al., 1997), by the World Water Council (Alcamo et al., 2000; Cosgrove and Rijsberman, 2000), and by Vörösmarty et al. (2000) as an approximate threshold of "high" or "severe" water stress.

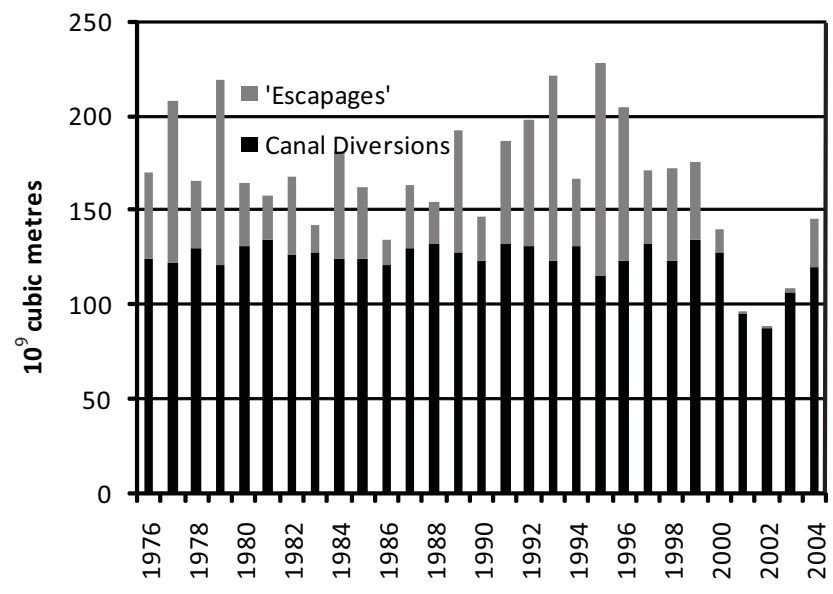

Fig. 2. Annual canal withdrawals and "escapages" to the sea (After Briscoe and Qamar, 2007).

In the case of Pakistan, on average $73 \%$ of the flow from the Indus is abstracted to the canal systems; already indicating a highly stressed system. Furthermore, in the drought years such as occurred from 2000 to 2003, virtually the entire flow was abstracted leaving only a trickle to support the ecology and to limit salt water intrusion on the lower river and to reach the Arabian Sea (Briscoe and Qamar, 2007) (Fig. 2).

\subsection{Per capita water availability}

Basins are also defined as being "water stressed" if they have a per-capita water availability below $1700 \mathrm{~m}^{3}$ per year (based on long-term average runoff) or as facing "water scarcity" when supplies drop below $1000 \mathrm{~m}^{3}$ per year. The use of per capita volume as an indicator of stress can be misleading as the requirement for irrigation which predominates in Pakistan is far greater per capita than for domestic and industrial use typical of developed countries; it also does not account for efficiency of use. Under this definition Briscoe and Qamar (2007) indicate that Pakistan has already fallen below the water stress threshold and will reach a condition of water scarcity by 2035. However, the Briscoe and Qamar estimate is based on a high value of available water (perhaps including groundwater) and a lower population than currently available estimates (UN, 2009). Therefore, the current and projected situation could be more severe than they have estimated.

The use of population in the denominator - "per capita" water availability - highlights the key role of assumed rates of population growth in the changing status of the water supply-demand balance. Population growth has been, and continues to be, high. From a total of 40 million in 1950, Pakistan's population grew to over 80 million in 1980 and to an estimated total of 185 million in 2010 (UN, 2009). Given this estimated population total and an annual runoff volume of $\sim 175 \mathrm{bcm}$ (the numerator), the per capita availability has already dipped below the water scarcity level of $1000 \mathrm{~m}^{3} /$ capita (Fig. 3). The UN medium population 


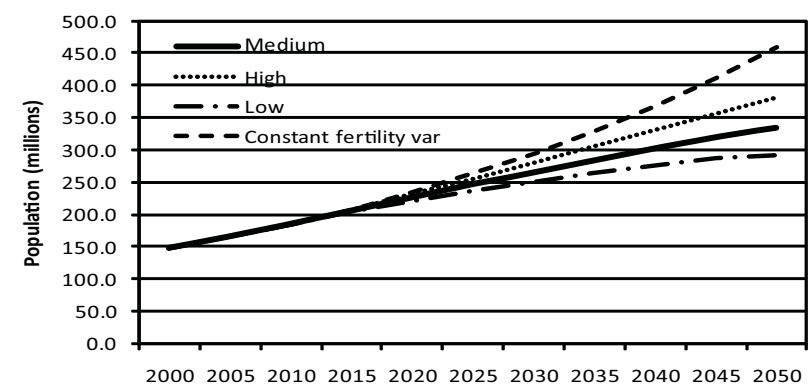

20002005201020152020202520302035204020452050 (a) (b)

Fig. 3. (a) Projected population growth showing four variants based on UN (2009) population estimates and (b) per capita water availability and available runoff of 175 billion cubic metres.

estimates of 246 and 335 million for 2025 and 2050 result in per capita estimates of only 711 and $522 \mathrm{~m}^{3}$. The UN (2009) provides different population growth trajectories. For 2050 these range from a low estimate of 293 million to a high estimate of 459 million based on a fertility rate assumed constant at its current level; these give per capita estimates of $599 \mathrm{~m}^{3}$ and $382 \mathrm{~m}^{3}$. Otherwise expressed, the population is rising and will continue to rise at approximately 4 million per year, necessitating significant increases in food production and associated increases either in water availability or efficiency of use.

\section{Water stress - changes to available supply}

Whilst the population, and thus demand for water, continues to rise, the supply is unlikely to increase. Briscoe and Qamar (2007) describe as a "sobering fact" that "there is no feasible intervention which would enable Pakistan to mobilize appreciably more water than it now uses". On the other hand, there are significant possibilities of reduced water availability for irrigation due either to reduction or reallocation of flow. Examples are:

1. decline of reservoir storage due to sedimentation

2. increase in domestic and industrial demand with increasing urbanisation

3. increase in environmental flows

4. decreased groundwater resources

5. potential impact of climate change on mountain sources.

\subsection{Reservoir sedimentation}

Changes in reservoir storage, either reductions due to sedimentation or increases due to the construction of new dams, do not change the overall volume of available water but they have serious consequences for the timing and the matching of flows to irrigation requirements and for hydropower production.
The River Indus and its tributaries carry a very high sediment load which has seriously affected the storage capacity of the two principal control dams, Tarbela and Mangla, on the Indus and Jhelum. Sedimentation resulted in a reduction of $28 \%$ in the initial capacity of $13.9 \mathrm{bcm}$ of Tarbela by 2000 and the useful life of the dam is now estimated to be 85 years (Asianics, 2000). Earlier estimates (Tams, 1997; Attewill et al., 1998) had indicated a more rapid rate of sedimentation and that the reservoir would largely be filled with sediment by 2030. Similarly, the capacity of Mangla was reduced by $20 \%$ by 2007 , although a current project to raise Mangla will soon restore the capacity to an amount greater than when originally constructed. Nevertheless, unless new storage dams are built there will be a progressive reduction in active storage which will seriously limit the capacity to transfer surplus summer flow to the winter (wheat) crop and downstream irrigation will return to run-of-river management.

A particular problem for Tarbela is the advance of the sediment delta which is approaching the dam's intake tunnels to the hydroelectric power station which satisfies nearly $20 \%$ of the country's demand for electricity. If the sediment delta were to reach the intake tunnels to the power house, the situation would be irreversible resulting in a cessation of power production and the transfer of all irrigation releases to be made via the spillways (Tate and Farquharson, 2000). Such a reduction in power capacity would have implications not only for domestic users but also for alternative groundwater sources of irrigation, dependent partly on electrical pumps.

Measures to manage sediment inflow and accumulation (Morris and Fan, 1997) have limited applicability for Tarbela and Mangla. Asianics (2000) ruled out sediment erosion control on the Tarbela catchment although the construction of the planned Basha reservoir $315 \mathrm{~km}$ upstream from Tarbela would reduce input to Tarbela. The dredging of sediments (136 $\mathrm{m}$ tonnes input annually) is impractical. A TAMS (1997) proposal for sediment sluicing from newlyconstructed high capacity outlets has been rejected. However, operating policies have been adopted to manage the distribution of sediments within the reservoir and to protect 
low level intakes. Further measures to adjust rule curves to increase sediment evacuation seem feasible (Khan and Tingsanchali, 2009).

\subsection{Increase in domestic and industrial demands}

With an increase in population there will be an inevitable increase in domestic water demand which will be accelerated with increased urbanisation. Urban population has grown from 20 million in 1980 to 70 million in 2000 with an associated growth in manufacturing industry. Although domestic demands are currently small in comparison with irrigation demands, Briscoe and Qamar (2007) suggest that they are expected to grow from $4 \%$ to $15 \%$ of aggregate water demand in the next twenty years. Both urban and rural domestic water supplies are mainly met from groundwater and locally aquifers are already being drawn down rapidly, thus conflicting with abstractions for irrigation.

\subsection{Increase in environmental flows}

Whilst there are many vulnerable ecosystems within the Indus Basin, including wetlands, floodplains and riparian areas which have been or may be affected by upstream interventions, the main concern is for residual freshwater flows to the Indus delta (Habib, 2006). The lower Indus has seen significant seawater intrusion up to $100 \mathrm{~km}$ upstream with resulting effects on riparian livelihoods and loss of biodiversity, including degradation of mangrove ecosystems, fish populations and the endangered Indus dolphin. Whereas a 1991 Water Accord between the provinces recognised the need for a residual flow to the delta of 10 million acre feet $(12.3 \mathrm{bcm})$, no formal policy or institutional mechanism has yet been adopted to make environmental water allocations. There is a clear need for such environmental allocations to be made not only for a minimum residual flow but also to provide a measure of flow variability that mimics the natural river regime (Richter et al., 1997). However, achieving a balance between environmental needs and ensuring food security through irrigation water use must also be addressed. Given the low irrigation water productivity (see Sect. 6.3), additional environmental flows could more readily be delivered by measurement and effective control and use of canal diversions than by blanket opposition to new dams on the upper Indus - which has typified the response of lower river users.

\subsection{Reduced groundwater availability}

Groundwater plays an important role in supplementing surface water abstraction and now provides more than $40 \%$ of water used for irrigation, mainly in the Punjab (Briscoe and Qamar, 2007). Groundwater, which is fed by seepage from the river and leakage from canals and distribution system, provides an alternative to surface storage in Mangla and
Tarbela, of transferring summer surplus to meet winter and spring deficit. Loss of water resources related to groundwater management could come from two opposed directions. Too little use of groundwater (or over-irrigation from surface sources) leads to a rising water table and the risk of waterlogging and salinity; too much use leads to falling water tables and the risk that extraction could become technically or economically infeasible (Shah et al., 2006).

Before the widespread development of irrigation in Pakistan, the water table over much of the lowlands was tens of metres below the surface. Leakage from the irrigation system through the first half of the twentieth century raised the water level and associated salts to the crop root zone over wide areas with dramatic loss of productive capacity due to the combined impact of waterlogging and/or salinity. By the early 1960 s, an estimated $23 \%$ of the country's land suffered to varying degrees from waterlogging and salinity and an area of 40000 ha was being lost annually (Elgabaly, 1977).

However, the situation has been partially reversed over the northern plains. Initial response was through a series of Salinity Control and Reclamation Projects (SCARPs) commencing in the late 1950s. The project aimed at lowering the groundwater table by providing vertical drainage through large capacity, deep tubewells (Qureshi et al., 2008). Under SCARP about 13500 publicly owned and operated tubewells were installed. However, the main change came about not primarily as a result of central planning but by the independent decisions of farmers to use groundwater as a substitute or to supplement for direct river irrigation. Farmers found that the canal system was too inflexible and provided water which was either too much, too little or at the wrong time; groundwater provides a decentralized "on-demand" source of water and enables farmers to greatly increase their crop yields and incomes. The result of this abstraction of groundwater by tubewells has been to draw down the water table and leach salt out of the root zone, thus reducing both the extent and severity of waterlogging and salinity. Habib (2006) indicates that groundwater abstraction from over 600000 tubewells has now reached nearly $70 \mathrm{bcm}$ per year.

However, salinity and waterlogging remain serious problems especially in irrigated areas of Sindh where much of the groundwater is naturally saline (of marine origin) and thus unsuitable for irrigation as a substitute for canal diversions. Since the area of waterlogging appears to be related directly to the amount of water diverted in the previous year (Briscoe and Qamar, 2007), the joint management of surface and groundwater sources is a key requirement.

Reduction in groundwater resources could also result from the opposing effect of over-abstraction, especially in the Punjab where abstraction exceeds the rate of recharge and the groundwater is being effectively "mined" both for irrigation and urban use. If water table levels continue to fall, they will eventually reach a point where it is no longer practicable to extract (Khan et al., 2008). The cost of pumping either by electrical pumps or the more common diesel 
pumps is likely to rise sharply with diminishing world oil resources. Petroleum products already constitute Pakistan's single largest import category.

\section{The potential effects of climate change}

The potential impact of climate change on water resources has already been outlined in the introduction but the evidence remains conflicting as to whether the change will have a positive or negative effect on water resources. The expectation of severely reduced resources expressed by Rees and Collins (2005) and the Briscoe and Qamar (2007) rests on two assumptions: that the effect of rising temperature on glacier melt is the primary impact on water resources; and that temperatures in the Upper Indus will rise in line with global climate change projections. However, both these assumptions are questionable.

Archer (2003) has shown that river flow in the Indus does not depend uniquely on glacier melt but also depends on seasonal snowmelt and rainfall - thus giving three distinct regimes relating climate to river flow:

1. a nival regime at middle altitudes where flow is dependent on the melting of seasonal snow accumulated during the preceding winter and spring

2. a glacial regime at very high altitudes where river flow is closely dependent on summer temperature

3. a rainfall regime dependent on runoff from concurrent rainfall mainly during the monsoon season.

\subsection{The nival regime}

Of these three regimes, the greatest contribution to flow comes from the nival regime. The area of seasonal snow is an order of magnitude greater than the area of perennial snow and ice, although the area diminishes and cover is depleted through the melt season. In this zone, including the greater part of the upper Jhelum basin (Archer and Fowler, 2008), winter precipitation and summer runoff are significantly positively correlated. Hence trends in winter precipitation are likely to have the most significant impact on runoff.

Archer and Fowler (2004) investigated historical trends in winter precipitation which mainly originates from westerly disturbances. They found upward trends in winter precipitation (October to March) at all stations across the region between 1961 and 1999 with three out of ten relationships being significant $(p>0.05)$.

In contrast to the glacial regime, the relationship between runoff and temperature on snowmelt fed catchments is consistently negative both with respect to concurrent summer temperature and prior season temperature (Archer, 2003; Archer and Fowler, 2008). Singh and Bengtsson (2005) suggest that the negative link between temperature and runoff is explained by greater evaporative losses from the snow cover under higher temperatures and thus reduced runoff. They estimate a reduction in runoff of $\sim 18 \%$ for a $2^{\circ}$ rise in summer temperature. The observed decline in summer temperature would, in contrast, tend to result in increased summer runoff. The negative link between preceding seasonal temperature and summer runoff combined with observed rising winter and spring temperature would tend to reduce summer runoff.

There are two potential limitations to this analysis.

1. The trend analysis was limited to the available longterm climate stations which are invariably located on valley floors and there is the possibility that they do not represent trends at higher elevations which receive much higher precipitation. However, the fact that the precipitation at these valley stations is strongly correlated with runoff originating at higher elevations indicates that precipitation measurements at valley level provide a satisfactory index of conditions at levels where snow is accumulating and melt occurring (Archer, 2003; Archer and Fowler, 2004).

2. Historic trends may not persist into the future (Milly et al., 2008). Updating of UIB precipitation trends to 2006, and including the drought years from 2000 to 2003, degrades the statistical significance of the trends. The IPCC (2007) projects precipitation increases in winter and spring for the "Tibetan Plateau" grid box, which includes but is larger than the UIB. The projected increases to 2039 vary between a $10 \%$ and $14 \%$ increase in winter between low and high emission scenarios and between $6 \%$ and $7 \%$ for spring. However, as these climate model projections are at a very coarse scale $(\sim 300 \mathrm{~km}$ grid boxes) and will not provide adequate simulation of local processes over complex terrain, the projections are highly uncertain (Buytaert et al., 2010).

\subsection{The glacial regime}

The glacial regime, on which dire predictions have been made, plays an important part in the flow of very high catchments such as the Shyok, Hunza and Shigar Rivers, whose combined flow represents an average of less than $30 \%$ of the flow in the Indus to the margins of the mountains. In these catchments there is a high and positive correlation between summer runoff and summer temperature as measured at valley stations (Archer, 2003; Fowler and Archer, 2006). In contrast to catchments of the nival regime, there is no significant correlation with preceding winter precipitation. Here, trends in spring and summer temperature will have the greatest impact on trends in runoff. This leads to the conclusion with respect to application of global temperature rise that runoff will initially increase but, with declining glacier mass, will 
ultimately fall sharply (Rees and Collins, 2005). Immerzeel et al. (2008) used a coarse resolution global database to assess long term temperature trends from 1972 to 2002 and concluded that there is a strong warming trend in all seasons although weakest in summer. He also concluded that the warming trend increased at higher elevations.

In contrast, Fowler and Archer (2006), using observed records from valley stations for data to 1999 , found that although winter and annual temperatures were rising in line with global projections, summer temperatures, and particularly minimum temperatures, were actually falling. This reversal of trend in the summer months is not unique to the high Karakoram; Hussain et al. (2005) and Sheikh et al. (2009) show similar temperature falls in the monsoon period for most other parts of both the Upper and Lower Indus. Hence, Fowler and Archer (2006) show that as runoff in the River Hunza and summer temperature are correlated, the recent trend in flow is slightly downward (Fig. 4).

Evidence of climate change from glaciological observations in the Upper Indus Basin is not clear cut. The rugged and remote terrain deters field measurement of glacier mass balance. Field detection of changes has been limited to observation of terminus retreat or advance, and thickening or wasting of ablation zones. Such observations are incomplete indicators of conditions over the full elevation range (Oerlemans, 2000). Nevertheless, reports in the eastern and central Himalaya extending as far west as the Upper Chenab (Fig. 1) of negative mass balance (Berthier et al., 2007), reduction in glacier area (Karma et al., 2003; Kulkarni et al., 2007) and accelerating glacier retreat (Eriksson et al., 2009) do not appear to be replicated in the Karakoram. Hewitt (2007) notes that glacier recessions were observed in almost all Karakoram glaciers for most of the 20th century until the mid-1990s. Since then there has been thickening and advances in many non-surging glaciers, but confined to the highest watersheds of the central Karakoram. In surveys between 1997 and 2002 Hewitt (2005) notes 13 glaciers of intermediate size (10 to $20 \mathrm{~km}$ in length) and 16 disconnected tributaries of larger glaciers which were found to be advancing. Some large glaciers (40 to $70 \mathrm{~km}$ in length) exhibited 5 to $15 \mathrm{~m}$ of thickening in their ablation zones. However, at lower elevations glaciers continued to decline. Raina and Sangewar (2007) and Ganjoo and Koul (2009) indicate on the basis of field observation that the high level Siachen glacier has shown hardly any retreat in the last fifty years. Analysis of ice loss using satellite gravimetry from 2003 to 2009 (Matsuo and Heki, 2010) seems to confirm that glacier loss is reduced in the Karakoram compared both with the neighbouring Himalaya and the Pamir mountains to the west.

The evidence of falling summer temperatures and the lack in the Karakoram of widespread retreat of glaciers reported globally (Dyugerov and Meier, 2005; Cogley, 2009) and in mountain regions elsewhere (Paul et al., 2007, Alps; Arendt et al., 2002, Alaska; Ramirez et al., 2001 and Lopez et al., 2010, Andes) suggests a quite different response to climate
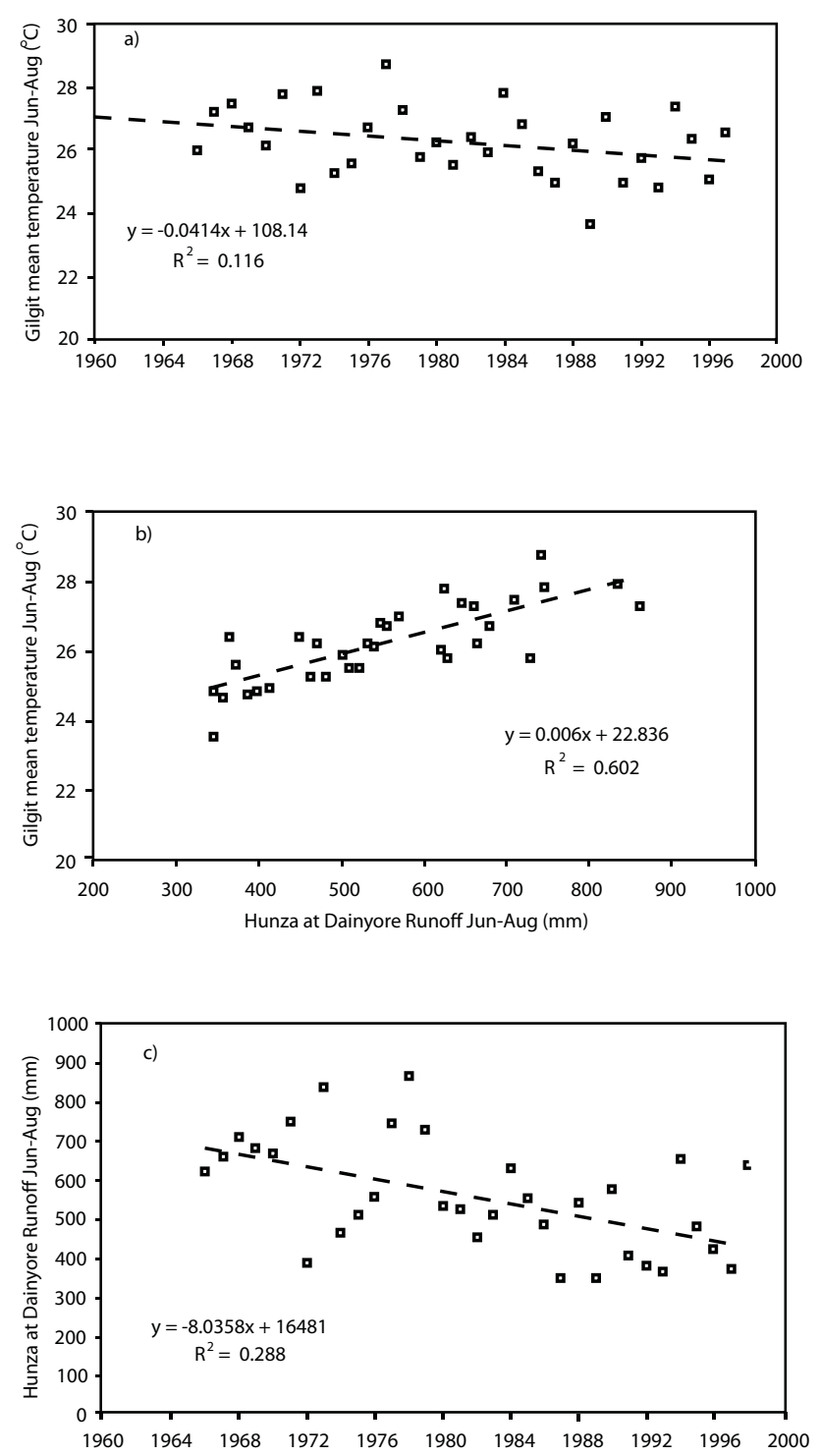

Fig. 4. Relationship between temperature at Gilgit and runoff at the River Hunza at Dainyor Bridge (a) Temperature trend from June to August; (b) Relationship between seasonal temperature and runoff (mm) from June to August; (c) Runoff trend from June to August (after Fowler and Archer, 2006).

change in the glacial regimes of the upper Indus from worldwide experience. However, there are again potential limitations to this analysis.

1. Temperature is merely a proxy, but the most reliable single proxy, for the full energy balance equations which could be better approximated by additional information on incoming solar radiation (or sunshine or cloud cover), wind speed and atmospheric humidity. Trends in glacier melt may also be affected by changes in albedo induced by growing black carbon emissions from India (Menon et al., 2010) and China (Xu et al., 2009). 
The limited ground based data sources for additional parameters are currently being investigated along with satellite based measurements of land surface temperature and cloud cover.

2. The trend analysis of temperature was limited to the available valley climate stations with the possibility of being unrepresentative of the broader region or of higher elevations. However, with respect to the use of individual valley stations to represent temperature variability over the broader region, cross correlation of station temperature across the UIB shows that seasonal temperature, especially in summer, is spatially conservative (Archer, 2004). In addition, the fact that the temperature at these valley stations is strongly correlated with runoff originating at higher elevations (Fig. 4) indicates that measurements at valley level provide a satisfactory index of conditions at levels where glacial melt is occurring. Mean seasonal temperature was found to provide a stronger correlation than either maximum or minimum temperature.

3. Historic trends may not persist into the future (Milly et al., 2008). However, downward summer temperature trends remain significant for observed data with the inclusion of recent years to 2006. In contrast, climate modelling results (IPCC, 2007) for the "Tibetan Plateau" grid box suggest a substantial temperature rise in every season. The projected increase for summer temperature to 2039 is around $1.7^{\circ} \mathrm{C}$ for both low and high emission scenarios and between $2.92^{\circ} \mathrm{C}$ and $3.74{ }^{\circ} \mathrm{C}$ between high and low emission scenarios to 2069. Such discrepancies need further investigation.

4. Whilst regression analysis finds no relationship between preceding precipitation and runoff in the following summer, trends in precipitation contribute to long term glacier mass balance and potentially to long term trends in runoff. Such impacts would not be detected in the regression analysis applied here.

\subsection{The monsoon rainfall regime}

The monsoon rainfall regime dominates on the southern foothills of the Himalaya and also over the plains to the south but with much reduced totals. Although the seasonal volume of runoff resulting from rainfall is lower than from glacial and nival sources, rainfall produces more intense runoff and is often the source of the highest floods on the margins of the mountains. Archer and Fowler (2004) show that there has been a statistically significant increase in summer rainfall in the upper Indus in the period since 1961. Moreover, the increase appears to be widespread over the greater part of Pakistan (Sheikh et al., 2009).
Historic trends and projections of the impacts of climate change on monsoon rainfall have received much more attention than glacial and nival regimes owing to their significance for the entire Indian sub-continent. The Intergovernmental Panel on Climate Change (IPCC, 2007) project an increase in summer precipitation but with uneven distribution across the Indian sub-continent and an increase in the frequency of intense precipitation in some parts. However, there are substantial inter-model differences in representing monsoon processes, including a lack of clarity over the effects of the El Nino Southern Oscillation (ENSO) which further contributes to uncertainty about future regional monsoon behaviour. Consequently, IPCC and Mani et al. (2009) indicate that quantitative estimates of projected precipitation change are uncertain and "it is likely that some local climate changes will vary significantly from regional trends due to the region's very complex topography and marine influences". The impact of climate change on monsoon precipitation trend in the Indus Basin in Pakistan therefore remains open to uncertainty.

\subsection{Climate change and water resources}

Given the above analysis there appears to be little evidence from any of the three regimes, nival, glacial and rainfall, for substantial historical reductions in runoff available for water resources. However considerable uncertainty remains in our understanding of the meteorological origins of climate trends, of links between climate, glacial accumulation and ablation and runoff and why the Upper Indus should differ in its response to climate change from other mountain regions of the world.

\section{The challenge of sustainability in water resources}

Although the focus here is on responses to climate change in the mountains, climate change cannot be considered in isolation from other problems of ensuring sustainable water resources. Responses can be considered in terms of availability of data, scientific capacity for analysis and management response to developing conditions.

\subsection{Data availability}

Climate and river flow data for the Upper Indus Basin fall far short of the WMO (1994) recommendation for density in rugged mountainous areas. For example, for nonrecording precipitation, the recommendation is for one gauge per $250 \mathrm{~km}^{2}$, whereas the actual density is of less than one gauge per $5000 \mathrm{~km}^{2}$ (and less than one per $10000 \mathrm{~km}^{2}$ if automatic gauges are excluded). Furthermore, gauges are predominantly at valley sites with the highest manual gauge at less than $2500 \mathrm{~m}$ and only three automatic gauges above $4000 \mathrm{~m}$, whereas the mean elevation of the Upper Indus (to Tarbela) is about $4500 \mathrm{~m}$ and the highest precipitation and 
melt contribution to runoff is from elevations above this level. The paucity of gauges is understandable in view of the logistical problems of installing and maintaining gauges in such harsh and rugged conditions. In spite of the limitation in gauge numbers, useful conclusions can be drawn on links between climate and runoff and on climate change, based on the discovery that both temperature and precipitation are highly correlated on a seasonal basis across the whole basin (Archer, 2003) and that climatic statistics from a single low-level station can provide a useful index of runoff on large catchments (Fowler and Archer, 2006) (Fig. 4). Inevitably further analysis will depend to a greater extent on satellite based remote sensing as a means of tracking snow covered area, snow water equivalent and glacier mass balance. Given the uncertainty in rates and direction of change in glacial mass balance, a more sustained programme of field observation and measurement is necessary.

In terms of sustainability of water resources, the most significant shortfall in measurement is with respect to very limited operational measurements in main, branch and distributary levels of the IBIS (Briscoe and Qamar, 2007). Measurement limitations and the consequent use of simple time-based water allocation practices restrict the ability to regulate flows, to make volumetric delivery within the network or to take advantage of seasonal flow forecasts from upland sources for planning (Archer and Fowler, 2008; Majeed, 1992, 2009).

\subsection{Scientific capacity for analysis}

Pakistan has been a slow starter with respect to climate change and associated analysis. However, climate change science took a major step forward with the creation of the GCISC (Global Change Impact Studies Centre) in 2002. With strong governmental backing the Centre has built up a multi-disciplinary team including climatologists, glaciologists and hydrologists and is carrying out work to monitor and analyse current and likely future trends in climate and glaciology and their impact on socio-economic development (Sheikh et al., 2009). At the same time, the research capacity of the PMD (Pakistan Meteorological Department) and academic institutions has been strengthened. In 2004 the PMD launched the Pakistan Journal of Meteorology available at: www.pakmet.com.pk/rnd/rnd\{_\}files/page707.htm, providing the opportunity for local dissemination of knowledge and expertise including on climate change.

With respect to glaciology, the only sustained monitoring and analysis has been carried out by Hewitt (1968, 1998, 2005). His work was boosted for a time by a collaborative programme with Canadian support (Hewitt and Young, 1993) with an important outcome being the setting up of a network of 20 automatic weather stations at levels between 2000 and $4700 \mathrm{~m}$. Some records are now of 15 years duration and are becoming useful for trend assessment. A further development has been the compilation of a baseline inventory of Upper Indus glaciers and glacial lakes using Land- sat ETM + (Roohi, 2007). A total of 5218 glaciers and 844 glacial lakes were identified and described. However, field study of glaciers and glacial processes remains weak.

\subsection{Management response to changing conditions}

Understanding of the potential impact of climate change in Pakistan remains uncertain so there may therefore be some justification in the limited practical response to date. However, future managerial capacity may be judged on the basis of the history of response to other environmental and social changes which affect water resources sustainability. These include the inexorable rise in population, the consequent growing water requirement for food security, conflicts for water use with the environment and domestic use, the loss of storage through reservoir sedimentation and the management of salinity and waterlogging. Management of the irrigation system and the need for new storage reservoirs are cited as examples. Government and managerial response to these issues have been fragmentary at best.

A key to sustainable water use is integrated management of reservoirs and irrigation systems. The current subdivision of responsibility, for the control reservoirs with the Water and Power Development Authority (WAPDA) and distribution with the Provincial Irrigation and Drainage Authorities (PIDA), has limited ability to make best use of available water. Productivity per unit of water is $40 \%$ lower than in neighbouring parts of India and 50\% lower than in the United States (Briscoe and Qamar, 2007). The lack of measurement and control result in farmers suffering variously from excess water (and salinity), too little water, or water at the wrong time. Insufficient effort has been put into precise levelling of irrigated fields so that lower areas are overwatered to ensure supplies to higher areas. Private abstractions from groundwater remain unlicensed; hence no overall control can be maintained on the balance between abstraction and recharge. Vested interests of large landowners and irrigation officials (who make "discretionary releases" for personal gain) oppose changes to the current system (Briscoe and Qamar, 2007). Increasing water productivity could buy time against increasing demand and reducing supplies.

When the Indus Basin Works were being planned, it was clear that the construction of Tarbela and Mangla was not a final solution. High silt loads and declining storage were anticipated and the need for replacement recognised. The rapid rise in population and water demand now make the construction of a major new storage essential. Yet in spite of proposals and detailed plans for dams at Kalabagh (downstream from Tarbela) and Basha (upstream from Tarbela) there is still no decision to proceed with construction.

Underlying the failure to take effective action either with respect to irrigation management or construction of new storages is the pervasive lack of trust. As Habib (2004) notes, "facts about water remain controversial and all domestic water issues are explained in the context of provincial 
antagonism". This is particularly the case for dam construction for which the most strident opposition has come from political parties and individuals in Sindh who surmise that Punjab will be the greatest beneficiary and that Sindh will lose its share both of water and revenues from power production. There is justification for concern in the view that residual flow to the Arabian Sea is "wastage" (Asrar-ul-Haq et al., 1997) or "escapages" (Tarar, 1997) rather than an important element of environmental sustainability. Nevertheless, it is clear that all will lose out if new storages are not built. If the ability to store surplus water from summer to release for the rabi crop is lost, Sindh will be the greatest loser since the option of using groundwater for storage is not widely available. The Briscoe and Qamar (2007) note that "the discussion of dams has become a vehicle for a host of unrelated historical and current political grievances". The prospects for effective adaptation to climate change are not high.

\section{Conclusion - meeting the challenge to sustainability in water resources}

Pakistan faces a network of interlinked challenges in which water resources plays a key role. The availability of water resources may limit the ability to ensure food security for a population that is continuing to grow rapidly. Squeezing the last drop out of available water to provide food will limit the amount that can be used to maintain ecosystems such as the Indus delta. Urban growth and industrialisation will demand their share of water resources. Water resources, especially in the spring, will gradually diminish as reservoir storage is taken up by sediment unless new large reservoirs are built. Reservoir sedimentation will also limit the ability to generate hydro electric power to meet the growing demand for domestic and industrial energy. The alternative of using groundwater as a means of securing water supply for the spring (rabi) crop may diminish as water tables fall and pumping becomes impractical. Economics has a role to play given that practical solutions to water resource management require large investments which will have to compete with the national needs for security, health and education of the population.

In the face of these daunting challenges, the effect of climate change is expected to play a minor role, particularly given the possibility that at least one, and perhaps all three, of the identified climate-runoff regimes will result in more rather than less water being available. Nevertheless analysis and the understanding of the linkage of climate, glaciology and runoff is still far from complete; recent past climate experience may not provide a reliable guide to the future. There is the possibility that although average volumes may increase, the annual variability may also increase, the seasonality of flows may alter, and rainfall and flooding may intensify. There is a need to build up the knowledge base of the mountain environments from which the greater part of the water resources originates. This will require improved education and a wider dissemination of scientific knowledge and application. Above all it will require better integrated management of water resources in which decisions are made on the basis of verifiable measurements and conflicts in water use acknowledged and compromises made.

Acknowledgements. Funds for travel between the UK and Pakistan and for capacity building activities were provided by the British Council through its PMI2Connect and INSPIRE research exchange award programmes. Nathan Forsythe was supported by a Graduate Research Fellowship award from the US National Science Foundation. Hayley Fowler was supported by NERC Postdoctoral Fellowship award NE/D009588/1 (2006-2010).

The authors also acknowledge the helpful comments of two anonymous reviewers and an interactive comment by Etienne Berthier to the HESS Discussion paper. WE wish to thank the Pakistan Meteorological Department and the Water and Power Development Authority for the provision of climate and flow data.

Edited by: D. Viviroli

\section{References}

Akhtar, M., Ahmad, N., and Booij, M. J.: The impact of climate change on the water resource of Hindukush-KarakorumHimalaya region under different glacier coverage scenarios, J. Hydrol., 355, 148-163, 2008.

Alcamo, J., Henrichs, T., and Rösch, T.: World water in 2025 global modeling scenarios for the World Commission on Water for the 21st Century, World Water Series Report no. 2, Centre for Environmental Systems Research, University of Kassel, Germany, 2000.

Alcamo, J., Döll, P., Henrichs, T., Kaspar, F., Lehner, B., Rösch, T., and Siebert, S.: Global estimates of water withdrawals and availability under current and future "business-as-usual" conditions, Hydrol. Sci. J., 48, 339-348, 2003.

Archer, D. R.: Contrasting hydrological regimes in the upper Indus Basin, J. Hydrol., 274, 198-210, 2003.

Archer, D. R.: Hydrological implications of spatial and altitudinal variations in temperature in the upper Indus basin, Nordic Hydrol., 35(3), 209-222, 2004

Archer, D. R. and Fowler, H. J.: Spatial and temporal variations in precipitation in the Upper Indus Basin, global teleconnections and hydrological implications, Hydrol. Earth Syst. Sci., 8, 4761, doi:10.5194/hess-8-47-2004, 2004.

Archer, D. R. and Fowler, H. J.: Using meteorological data to forecast seasonal runoff on the River Jhelum, Pakistan, J. Hydrol., 361, 10-23, 2008.

Arendt, A. A., Echelmeyer, K. A., Harrison, W. D., Lingle, C. S., and Valentin, V. B.: Rapid wastage of Alaska glaciers and their contribution to rising sea level, Science, 297(5580), 382-386, 2002.

Asianics Agro-Dev. International (Pvt) Ltd.: Tarbela Dam and related aspects of the Indus River Basin, Pakistan, a WCD case study prepared as an input to the World Commission on Dams, Cape Town, 2000, available at: www.adb.org/water/ Topics/Dams/pdf/cspkmain.pdf, last access: March 2010.

Asrar-ul-Haq, Shahid, B. A., and Shakir, A. S.: Indus Basin water resources: sustainability concerns and optimisation strategies, 
edtied by: Tariq, A. R. and Latif, M., Water for the 21st Century: Demand, Supply, Development and Socio-environmental Issues, Proceedings of an International Symposium, Centre of Excellence in Water Resources Engineering Publications, Lahore, 110, 61-76, 1997.

Attewill, L. J. S., White, W. R., Tariq, S. M, and Bilgi, A.: Sediment management studies of Tarbela Dam, Pakistan, The prospect for reservoirs in the 21st century, (Proceedings of the 10th Conference of the British Dam Society, Bangor Wales), Thomas Telford, 212-225, 1998.

Bates, B. C., Kundzewicz, Z. W., Wu, S., and Palutikof, J. P.: Climate Change and Water, Technical Paper of the Intergovernmental Panel on Climate Change, Geneva, IPCC Secretariat, 210 pp., 2008.

Berthier, E., Arnaud, Y., Kumar, R., Ahmad, S., Wagnon, P., and Chevallier, P.: Remote sensing estimates of glacier mass balances in the Himachal Pradesh (Western Himalaya, India), Remote Sens. Environ., 108(3), 327-338, 2007.

Briscoe, J. and Qamar, U.: Pakistan's Water economy running dry, Oxford University Press, Karachi, Commissioned by World Bank, 2007.

Buytaert, W., Vuille, M., Dewulf, A., Urrutia, R., Karmalkar, A., and Célleri, R.: Uncertainties in climate change projections and regional downscaling in the tropical Andes: implications for water resources management, Hydrol. Earth Syst. Sci., 14, 12471258, doi:10.5194/hess-14-1247-2010, 2010.

Cogley, J. G.: Geodetic and direct mass-balance measurements: comparison and joint analysis, Ann. Glaciol., 50(50), 96-100, 2009.

Cosgrove, W. and Rijsberman, F.: World Water Vision: Making Water Everybody's Business, World Water Council, Earthscan Publications, London, UK, 2000.

Dyurgerov, M. D. and Meier, M.: Glaciers and Changing Earth System: A 2004 Snapshot, Boulder (Colorado): Institute of Arctic and Alpine Research, University of Colorado, 2005.

Elgabaly, M. M.: Problems and Effects of Irrigation in the Near East Region, in: Arid land irrigation in developing countries: environmental problems and effects, edited by: E. Barton Worthington, Pergamon, Oxford, 239-248, 1977.

Eriksson, M., Xu, J., Shrestha, A. B., Vaidya, R. A., Nepal, S., and Sandström, K.: The changing Himalayas: Impact of climate change on water resources and livelihoods in the greater Himalayas, Kathmandu, ICIMOD, 2009.

Fowler, H. J. and Archer, D. R.: Hydro-climatological variability in the Upper Indus Basin and implications for water resources, in: Regional Hydrological Impacts of Climatic Change - Impact Assessment and Decision Making, edited by: Wagener, T., Franks, S., Gupta, H. V., Bøgh, E., Bastidas, L., Nobre, C., and Galvão, C. de O., IAHS Publ., 295, 131-138, 2005.

Fowler, H. J. and Archer, D. R.: Conflicting Signals of Climate Change in the Upper Indus Basin, J. Climate, 19, 4276-4292, 2006.

Ganjoo, R. K. and Koul, M. K.: Is the Siachen glacier melting?, Current Science, Scientific Correspondence, 97(3), 311-313, 2009.

Habib, Z.: Pakistan: Indus Basin water issues, South Asian Journal, South Asian Free Media Association, available at: www. southasianmedia.net/Magazine/Journal/previousissue6.htm (last access: March 2010), 2004.
Habib, Z.: Water Management and Reservoirs in Pakistan, South Asian Journal, South Asian Free Media Association, available at: http://www.southasianmedia.net/Magazine/Journal/ previousissues11.htm (last access: March 2010), 2006.

Herodotus : An account of Egypt: being the second book of his Histories called Euterpe, translated G. C. Macauley, 5th Century BC.

Hewitt, K.: The freeze-thaw environment of the Karakoram Himalaya, Can. Geogr., 12, 85-98, 1968.

Hewitt, K.: Glaciers receive a surge of attention in the Karakoram Himalaya, Eos, Trans. Amer. Geophys. Union, 79, 104-105, 1998.

Hewitt, K.: The Karakoram Anomaly? Glacier Expansion and the "Elevation Effect", Karakoram Himalaya, Mt. Res. Dev., 25(4), 332-340, 2005.

Hewitt, K.: Tributary glacial surges: an exceptional concentration at Panmah Glacier, Karakoram Himalaya, J. Glaciol., 53, 181-188, 2007.

Hewitt, K. and Young, G. J.: The Snow and Ice Hydrology Project; a Pakistan-Canada research and training programme, Snow and Glacier Hydrology (Proceedings of the Kathmandu Symposium, November 1992), IAHS Publ., 218, 49-58, 1993.

Hussain, S. S, Mudasser, M., Sheikh, M. M., and Manzoor, N.: Climate change and variability in mountain regions of Pakistan implications for water and agriculture, Pakistan J. Meteorol., 2(4), 79-94, 2004.

Immerzeel, W. W., Droogers, P., de Jong, S. M., and Bierkens, M. F. P.: Large-scale monitoring of snow cover and runoff simulation in Himalayan river basins using remote sensing, Remote Sens. Environ., 113(1), 40-49, doi:10.1016/j.rse.2008.08.010, 2008.

IPCC: Climate Change 2007: The Physical Science Basis, Contribution of Working Group I to the Fourth Assessment Report of the Intergovernmental Panel on Climate Change, edited by: Solomon, S., Qin, D., Manning, M., Chen, Z., Marquis, M., Averyt, K. B., Tignor, M., and Miller, H. L., Cambridge University Press, Cambridge, UK and New York, NY, USA, 2007.

Karma, A. Y., Naito, N., Iwata, S., and Yabuki, H.: Glacier distribution in the Himalayas and glacier shrinkage from 1963 to 1993 in the Bhutan Himalayas, Bulletin of Glaciological Research, 20, 29-40, 2003.

Khan, N. M. and Tingsanchali, T.: Optimization and simulation of reservoir operation with sediment evacuation: a case study of the Tarbela Dam, Pakistan, Hydrol. Process., 23(5), 730 -747, 2009.

Khan, S., Rana, T., Gabriel, H. F., and Ullah, M. K.: Hydrogeologic assessment of escalating groundwater exploitation in the Indus Basin, Pakistan Hydrogeol. J., 16(8), 1635-1654, 2008.

Kulkarni, A. V., Bahuguna, I. M., Rathore, B. P., Singh, S. K., Randhawa, S. S., Sood, R. K., and Dhar, S.: Glacial retreat in Himalaya using Indian remote sensing satellite data, Curr. Sci. India, 92(1), 69-74, 2007.

Lopez, P., Chevallier, P., Favier, V., Pouyaud, B., Ordenes, F., and Oerlemans, J.: A regional view of fluctuations in glacier length in southern South America, Global Planet. Change, 71(1-2), 85108, 2010.

Majid, A.: Forecasting of seasonal and 10-daily inflows to Mangla reservoir, Final Report to PCRWR Ministry of Science and Technology, 1992.

Majid, A., Hussain, T., and Asghar, M. R.: Long and Medium Range Forecast for Inflow at Tarbela, Pakistan J. Meteorol., 
5(10), 37-52, 2009.

Mani, N. J., Suhas, E., and Goswami, B. N.: Can global warming make Indian monsoon weather less predictable?, Geophys. Res. Lett., 36, L08811, doi:10.1029/2009GL037989, 2009.

Matsuo, K. and Heki, K.: Time-variable ice loss in Asian high mountains from satellite gravimetry, Earth Planet. Sc. Lett., 290, 30-36, 2010.

Menon, S., Koch, D., Beig, G., Sahu, S., Fasullo, J., and Orlikowski, D.: Black carbon aerosols and the third polar ice cap, Atmos. Chem. Phys., 10, 4559-4571, doi:10.5194/acp-10-4559-2010, 2010.

Milly, P. C. D., Betancourt, J., Falkenmark, M., Hirsch, R. M., Kundzewicz, Z. W., Lettenmaier, D. P., and Stouffer, R. J.: Stationarity Is Dead: Whither Water Management?, Science, 319(5863), 573-574, 2008.

Morris, G. L. and Fan., J.: Reservoir Sedimentation Handbook: design and management of dams, reservoirs and watersheds for sustainable use, McGraw-Hill Book Co., New York, 848 pp., 1998.

Oerlemans, J.: Glaciers and climate change, A. A. Balkema Publishers, Rotterdam, 148 pp., 2001.

Qureshi, S., McCornick, P. G., Qadir, M., and Aslam, Z.: Managing salinity and waterlogging in the Indus Basin of Pakistan, Agr. Water Manage., 95(1), 1-10, 2008.

Raina, V. K. and Sangewar, C. V.: Siachen Glacier of Karakoram Mountains, Ladakh - Its Secular Retreat, Jour. Geol. Society of India, 70, 11-16, Bangalore, 2007.

Ramirez, E., Francou, B., Ribstein, P., Descloitres, M., Guérin, R., Mendoza, J., Gallaire, R., Pouyaud, B., and Jordan, E.: Small glaciers disappearing in the tropical Andes: a case-study in Bolivia: Glacier Chacaltaya (16 S), J. Glaciol., 47(157), 187-194, 2001.

Raskin, P., Gleick, P., Kirshen, P., Pontius, G., and Strzepek, K.: Water futures: assessment of long-range patterns and problems. Comprehensive assessment of the freshwater resources of the world, Stockholm Environment Institute, Stockholm, Sweden, 1997.

Rees, H. G. and Collins, D. N.: Regional differences in response of flow in glacier-fed Himalayan rivers to climatic warming, Hydrol. Process., 20(10), 2157-2169, 2005.

Richter, B. D., Baumgartner, J. V., Wigington, R., and Braun, D. P.: How much water does a river need?, Freshwater Biol., 37, 231-249, 1997.

Roohi, R.: Research on global changes in Pakistan, in: Mountain Witnesses of Global Changes: Research in the Himalaya and Karakoram: Share Asia Project, edited by: Baudo, R. Tartari, G., and Vuillermoz, E., Developments in Earth Surface Processes 10, Elsevier, Amsterdam, 2007.

Shah, T., Singh, O. P., and Mukherji, A.: Some aspects of South Asia's groundwater irrigation economy: analyses from a survey in India, Pakistan, Nepal Terai and Bangladesh, Hydrogeol. J., 14, 286-309, 2006
Sheikh, M. M., Manzoor, N., Adnan, M., Ashraf, J., and Khan, A. M.: Climate Profile and Past Climate Changes in Pakistan, GCISC-RR-01, Global Change Impact Studies Centre (GCISC), Islamabad, Pakistan, ISBN: 978-969-9395-04-8, 2009.

Shrestha, M. L., Wake, A. B., and Shrestha, P. A.: Recent Trends and Potential Climate Change Impacts on Glacier Retreat/Glacial Lakes in Nepal and Potential Adaptation Measures, OECD Global Forum on Sustainable Development, Development and Climate Change Paris, France, OECD, 5-14, 2004.

Shroder Jr, J. F., Bishop, M. P., Bulley, H. N. N., Haritashya, U. K., and Olsenholler, J. A.: Global Land Ice Monitoring from Space (GLIMS) Project Regional Center for Southwest Asia (Afghanistan and Pakistan), in: Development in Earth Surface Processes, 10 Mountains Witnesses of Global Changes, Elsevier Publishers, 187-207, 2007.

TAMS Consultants Inc., HR Wallingford Ltd. \& Institute of Hydrology: Tarbela Dam Sediment Management Study - Inception Report, Commissioned by Pakistan's Water and Power Development Authority (WAPDA), 1997.

Tarar, R. N.: Pakistan's surface water scenario in 21 st century and needed actions, edited by: Tariq, A. R. and Latif, M., Water for the 21st Century: Demand, Supply, Development and Socioenvironmental Issues, Proceedings of an International Symposium, Centre of Excellence in Water Resources Engineering Publications, 110, 49-60, Lahore, 1997.

Tate, E. L. and Farquharson, F. A. K.: Simulating Reservoir Management under the Threat of Sedimentation: The Case of Tarbela Dam on the River Indus, Water Resour. Manag., 14(3), 191-208, 2000.

UNDP, UNEP, World Bank, and WRI.: World Resources 2000-01 - People and Ecosystems, WRI, Washington DC, 2000.

United Nations: Population Division of the Department of Economic and Social Affairs, World Population Prospects: The 2008 Revision, available at: http://esa.un.org/unpp, last access: March 2010.

Vörösmarty, C. J., Green, P., Salisbury, J., and Lammers, R. B.: Global water resources: vulnerability from climate change and population growth, Science, 289, 284-288, 2000.

Wake, C. P.: Glaciochemical investigations as a tool to determine the spatial variation of snow accumulation in the Central Karakoram, Northern Pakistan, Ann. Glaciol., 13, 279-284, 1989.

World Bank: Water Resources Sector Strategy, Washington DC, 2003.

WMO (World Meteorological Organisation): Guide to Hydrological Practices, WMO-164, WMO, Geneva, 5th edition, 1994.

Xu, B., Cao, J., Hansen, J., Yao, T., Joswia, D. J., Wang, N., Wu, G., Wang, M., Zhao, H., Yang, W., Liu, X., and He, J.: Black soot and the survival of Tibetan glaciers, P. Natl. Acad. Sci., 106, 22114-22118, doi:10.1073/pnas.0910444106, 2009. 